\title{
Evaluation of maxillary sinus expansion in children due to maxillary first molar extraction
}

\section{Purpose}

This study is aimed at understanding the effects of maxillary first molar extraction on the expansion of maxillary sinus in children.

\section{Subjects and methods}

119 patients (aged 11-17 years) who had only one extracted maxillary first molar were included in the study. The superoinferior differences of the sinus floor position were measured in both dentate and edentulous sites on panoramic radiographs. The expansion of the maxillary sinus after maxillary first molar extraction was investigated in relation to fixed anatomic structures. The interorbital line (IL) and two zygomatic process lines (IZ) were used as a reference. The vertical distances between the IL and the inferior border of the maxillary sinus (IS) in edentulous (ISX) and in dentate sites $\left(I \mathrm{~S}_{\mathrm{T}}\right)$ were measured. The data was analyzed statistically.

\section{Results}

The amount of maxillary sinus expansion in ISX was statistically significant in comparison to $I S_{T}(p<0.001)$. The most prominent sinus expansions were found in subjects with extractions over six months prior to analysis $(p<0.001)$. A negative correlation was detected between the amount of maxillary sinus expansion and $\mathrm{IS}_{\mathrm{T}}(\mathrm{r}=-0.438, \mathrm{p}<0.001)$. There was a positive correlation between the amount of maxillary sinus expansion and $\mathrm{IZ}_{\mathrm{T}}(\mathrm{r}=23.8, \mathrm{p}<0.009)$.

\section{Conclusion}

This study showed that the extraction of one maxillary first molar resulted in a negligible amount of sinus expansion in children. The results could be attributed to there being only one tooth extraction and a transferring of functional forces to the area of the neighboring teeth.

Keywords: Maxillary sinus; sinus expansion; tooth extraction; panoramic radiography; children

\section{Introduction}

The expansion of paranasal sinuses begins at birth and continues with the development of the facial cranium (1). The maxillary sinus is the first sinus to develop, it starts growing in the fifth fetal month, reaches its final growth between 12-14 years of age and ends following the eruption of the $3^{\text {rd }}$ molars $(2,3)$.

Pneumatization of the sinus may be influenced by a number of factors including heredity and disuse atrophy. The dimensions of the maxillary sinus can be affected by the environmental factors, genetic diseases and infections (3). Wehrbein and Diedrich (4) reported a direct correlation between the amount of sinus expansion after tooth extraction and the projection length of roots into the sinus.

The extraction of the maxillary molar teeth results in dimensional changes with bone loss of the sinus floor (5). The rapid bone destruction can

\author{
Sinem Kuru' ${ }^{1}$, \\ Mustafa Mert Açıkgöz², \\ Arzu Pınar Erdem', \\ Gülsüm Ak², \\ Tamer Lütfi Erdem³, \\ Gamze Aren', \\ Elif Sepet ${ }^{1}$
}

\author{
'Department of Pediatric Dentistry, Faculty of Dentistry, \\ Istanbul University, Istanbul, Turkey \\ ${ }^{2}$ Department of Oral and Maxillofacial Surgery, Faculty of \\ Dentistry, Istanbul University, Istanbul, Turkey \\ ${ }^{3}$ Department of Dentomaxillofacial Radiology, Faculty of \\ Dentistry, Okan University, Istanbul, Turkey \\ Corresponding Author: Elif Sepet \\ E-mail: espt@istanbul.edu.tr \\ Received: April 11, 2018 \\ Revised: May 8, 2018 \\ Accepted: July 29, 2018
}

DOI: 10.26650/eor.20196934 
extend to the alveolar process, moreover, the bone doesn't regenerate to the preoperative level (5-7). Bone height can decrease alongside maxillary sinus extension into the alveolar process (8). Sinus expansion is clinically important during tooth extraction or an implant insertion (9).

The maxillary sinus may be accidentally opened during difficult tooth extractions (10). Sinus expansion has been investigated by some clinical studies with various results (11-15). Some studies have found an increase in size after molar extractions $(11,15)$, while other studies have reported no difference in sinus size between dentate and edentulous subjects $(12,16,17)$.

This study is aimed at understanding the effect of upper first molar extraction on the expansion of maxillary sinus in children. The main null hypothesis tested in the present study is that first molar extraction in children has no effect on maxillary sinus expansion.

\section{Subjects and methods}

\section{Study design}

The Ethics Committee of Istanbul University, Faculty of Medicine approved this study (2011/2108-895) and the subjects parents gave informed consent for them to participate in the study. The guidelines of the Helsinki Declaration were followed in this investigation.

Panoramic radiographs were taken from patients who received dental treatment at Istanbul University's Pediatric Dentistry and Oral-Maxillofacial Surgery Departments, Istanbul, Turkey. The panoramic radiographs were all obtained using a Kodak 8000 Digital Panoramic Machine (Carestream Health, Inc., Rochester, NY, USA) at kVp 6568; $\mathrm{mA}$ range varies between 2-3,2 for infants; 5-6.5 for adolescents. The subjects' selection criteria were as follows:

(1) extraction only of one maxillary first permanent tooth,

(2) no history of sinus diseases.

\section{Study population}

119 patients (aged 11-17 years) who had only one extracted maxillary first molar were included in the study. The superoinferior differences of the sinus floor position were measured both in dentate and edentulous sites on the panoramic radiographs and were obtained at least 6 months after tooth extraction.

Image analysis

We used the method which previously described by Sharan and Madjar (15) for evaluating vertical distances on panoramic radiographs. Expansion of the maxillary sinus after maxillary first molar extraction was investigated in relation to fixed anatomic structures. The interorbital line (IL) and two zygomatic process lines (IZ) were used as a reference. The reference lines were marked on the radiographs with a pencil then they were scanned and digitized. Adobe Photoshop 7.0 software was used to measure the distance between the interorbital line and the zygomatic process lines on images magnified by $200 \%$. The vertical distances between the IL and the sinus floor (IS) in edentulous (ISX) and in dentate sites (IST) were measured. The lengths of the

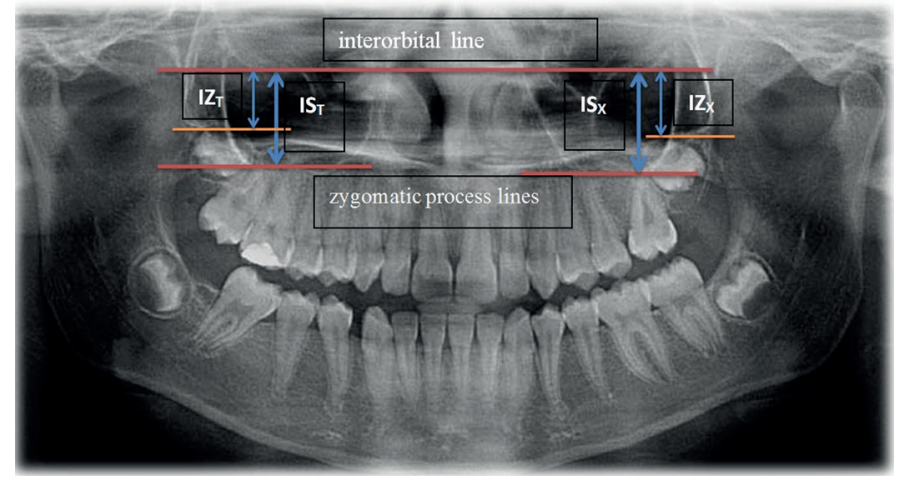

Figure 1. Interorbital line and two zygomatic process lines used as reference lines on panoramic radiographs.

vertical distances between the IL and IZ on both sides (IZX, IZT) of the jaw were also measured (Figure 1).

The ratio: IS/IZ was used to express the position of the sinus floor. The maxillary sinus pneumatization is calculated using the formula ISX- (IST*IZx/IZT). A positive value was evaluated as an inferiorly located sinus floor on the edentulous site. We repeated the measurements three times and used the mean value for statistical analysis.

\section{Statistical analysis}

Statististical analyses were performed using Statistical Package for Social Scince (IBM Corp. Released 2012. IBM SPSS Statistics for Windows, Version 21.0. Armonk, NY: IBM Corp, USA). Shapiro-Wilk, Mann-Whitney U and Spearman's Rho correlation tests were applied. Data was expressed as means and medians of the study groups. Confidence interval was set to $95 \%$ and $p$ values less than 0.05 were considered statistically significant.

\section{Results}

The number of patients, according to age and sex are presented in Table 1. The mean age of the subjects included in the study ( 69 boys, 50 girls) was $13.06 \pm 1.54$. Evaluation of ISX and IST parameters is presented in Table 2. There was no statistically significant differences between the investigated parameters. The mean values for maxillary sinus expansion according to time are presented in Table 3. The average length of time following tooth extraction

Table 1. Number of patients stratified by age and sex.

\begin{tabular}{lccc} 
Age (years) & Male & Female & Total \\
\hline 11 & $15(21.7 \%)$ & $7(14 \%)$ & $22(18.5 \%)$ \\
\hline 12 & $17(24.6 \%)$ & $8(16 \%)$ & $25(21 \%)$ \\
\hline 13 & $12(17.4 \%)$ & $18(36 \%)$ & $30(25.2 \%)$ \\
\hline 14 & $10(14.5 \%)$ & $8(16 \%)$ & $18(15.1 \%)$ \\
\hline 15 & $9(13 \%)$ & $7(14 \%)$ & $16(13.4 \%)$ \\
\hline 16 & $4(5.8 \%)$ & $2(4 \%)$ & $6(5 \%)$ \\
\hline Total & $2(2.9 \%)$ & $0(0 \%)$ & $2(1.7 \%)$ \\
\hline
\end{tabular}


Table 2. Evaluation of $I S_{X}$ and $I S_{T}$ parameters stratified by age and sex. (IS $S_{X}$ Vertical distance between the interorbital line (IL) and the sinus floor (IS) in edentulous site; IST: Vertical distance between the interorbital line (IL) and the sinus floor (IS) in dentate site, Mann Whitney U test; SD: standard deviation).

\begin{tabular}{|c|c|c|c|}
\hline \multirow{2}{*}{ Age } & \multirow{2}{*}{ Sex } & $\mathbf{I S}_{\mathbf{X}}$ & $\mathbf{I S}_{\mathbf{T}}$ \\
\hline & & Mean \pm SD (median) & Mean \pm SD (median) \\
\hline \multirow{2}{*}{11} & Boys & $20.27 \pm 1.87(20)$ & $18.53 \pm 1.55(18)$ \\
\hline & Girls & $19.57 \pm 0.98(20)$ & $17.29 \pm 2.14(18)$ \\
\hline & & 0.460 & 0.110 \\
\hline \multirow{2}{*}{12} & Boys & $20.41 \pm 2.18(20)$ & $19.18 \pm 1.88(19)$ \\
\hline & Girls & $19.88 \pm 2.85(19.5)$ & $19 \pm 3.07(19)$ \\
\hline & & 0.358 & 0.781 \\
\hline \multirow{2}{*}{13} & Boys & $20.17 \pm 1.95(20)$ & $19.25 \pm 3.6(18)$ \\
\hline & Girls & $19.5 \pm 1.34(19.5)$ & $18.28 \pm 1.27(18.5)$ \\
\hline & & 0.597 & 0.842 \\
\hline \multirow{2}{*}{14} & Boys & $20.6 \pm 2.17(20)$ & $18.8 \pm 2.9(18)$ \\
\hline & Girls & $21 \pm 2.33(21)$ & $19.13 \pm 2.53(19)$ \\
\hline & & 0.547 & 0.361 \\
\hline \multirow{2}{*}{$15-17$} & Boys & $21.73 \pm 2.84(21)$ & $20.67 \pm 3.27(19)$ \\
\hline & Girls & $21.22 \pm 3.35(21)$ & $19.22 \pm 3.42(19)$ \\
\hline & & 0.566 & 0.243 \\
\hline \multirow{2}{*}{ Total } & Boys & $20.65 \pm 2.25(20)$ & $19.32 \pm 2.7(19)$ \\
\hline & Girls & $20.12 \pm 2.25(20)$ & $18.56 \pm 2.39(19)$ \\
\hline & & 0.222 & 0.276 \\
\hline
\end{tabular}

Table 3. Maxillary sinus expansion according to time after extraction (Mann Whitney U test ${ }^{*} p<0.05$, SD: Standard deviation).

\begin{tabular}{lc|} 
Time & Sinus Expansion mean \pm SD (median) \\
\hline $0-6$ months & $-1.09 \pm 2.12(-0.4)$ \\
\hline $6-24$ months & $0.73 \pm 2.53(0.6)$ \\
\hline$p$ & $0.001^{*}$ \\
\hline
\end{tabular}

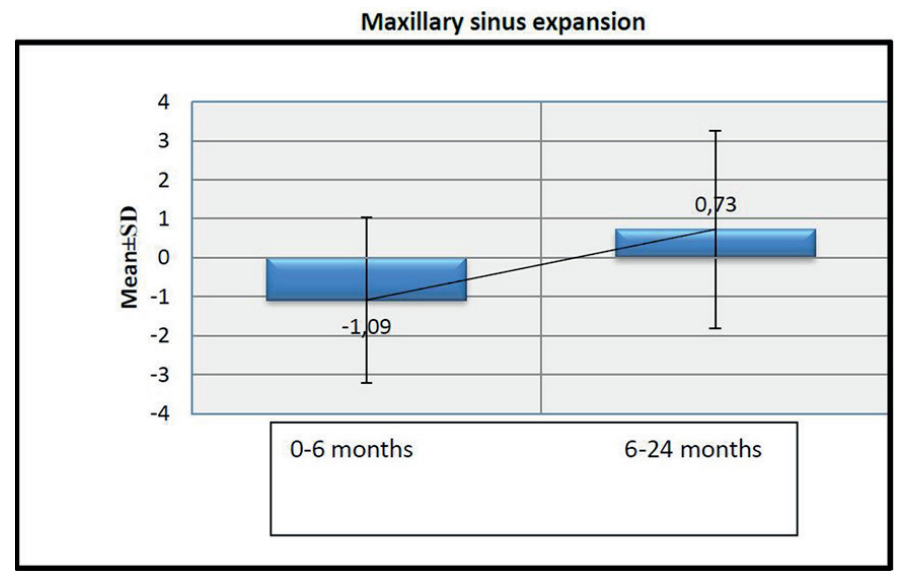

Figure 2. Maxillary sinus expansion stratified by time factor after extraction.

was $8.02 \pm 1.72$ months. The amount of maxillary sinus expansion significantly increased with the time intervals after extractions $(p=0.001)$. Those patients with extractions
Table 4. The evaluation of the correlations between the amount of maxillary sinus expansion and ISX, IST, IZX, IZT measurements (Sperman's rho * $p<0.05$, ISX: Vertical distance between the interorbital line (IL) and the sinus floor (IS) in edentulous site IST: Vertical distance between the interorbital line (IL) and the sinus floor (IS) in dentate site IZX: Vertical distance between the interorbital line (IL) and the zygomatic process line (IZ) in edentulous site IZT: Vertical distance between the interorbital line (IL) and the zygomatic process line (IZ) in dentate site).

\section{Maxillary sinus expansion}

\begin{tabular}{|c|c|c|}
\hline \multirow{2}{*}{$1 S_{X}$} & $r$ & 0.043 \\
\hline & $p$ & 0.645 \\
\hline \multirow{2}{*}{$\mathrm{IS}_{\mathrm{T}}$} & $r$ & -0.438 \\
\hline & $p$ & $0.001 *$ \\
\hline \multirow{2}{*}{$I_{X}$} & $r$ & -0.057 \\
\hline & $p$ & 0.535 \\
\hline \multirow{2}{*}{$I_{T}$} & $r$ & 0.238 \\
\hline & $p$ & $0.009 *$ \\
\hline
\end{tabular}

over six months presented the largest sinus expansions (Figure 2). Evaluation of the correlations between the amount of maxillary sinus expansion and ISX, IST, IZX, IZT measurements is presented in Table 4. A negative correlation was detected between the amount of maxillary sinus expansion and IST $(r=-0.438, p=0.001)$, (Figure 3$)$. There was a positive correlation between the amount of maxillary sinus expansion and IZT $(r=23.8, p=0.009)$, (Figure 4). 


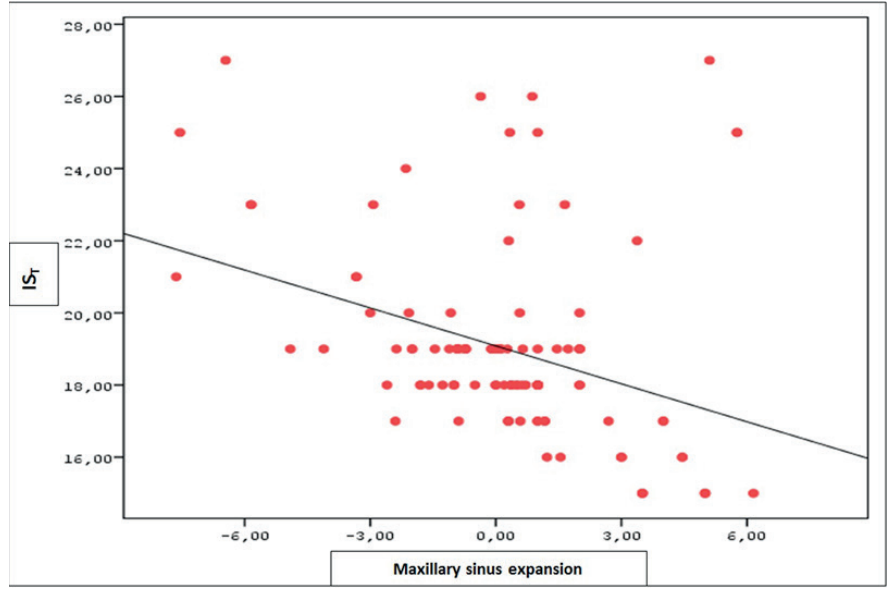

Figure 3. The negative correlation between the amount of maxillary sinus expansion and IST (IST: The vertical distance between the interorbital line (IL) and the sinus floor (IS) in dentate site).

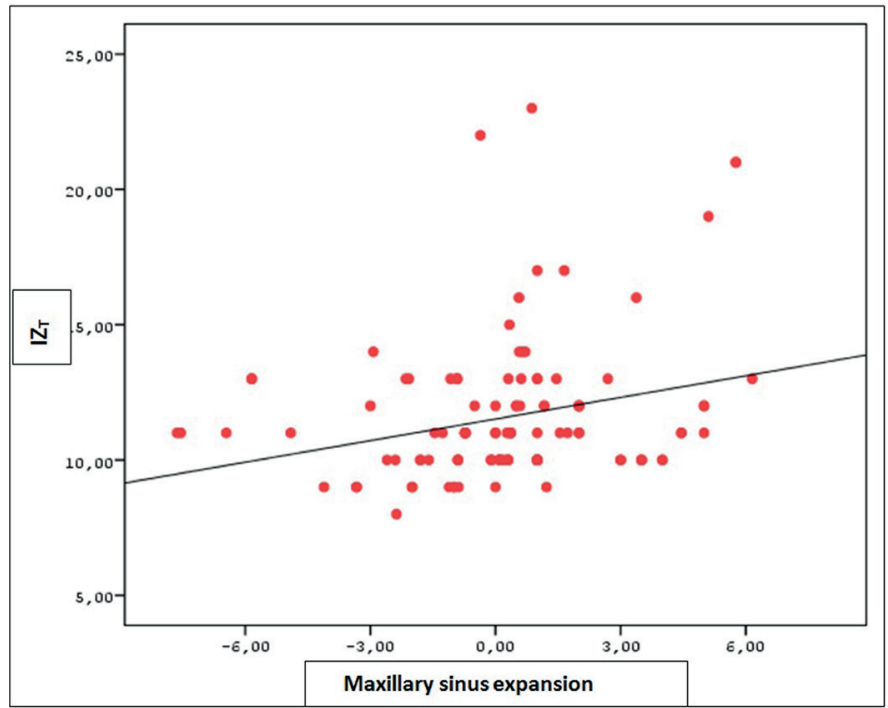

Figure 4. The positive correlation between the amount of maxillary sinus expansion and $I Z_{T}\left(I Z_{T}\right.$ : The vertical distance between the interorbital line (IL) and the zygomatic process line (IZ) in dentate site).

\section{Discussion}

This study documented the effect of only one upper first molar extraction on the expansion of maxillary sinus in children. Both dentate and edentulous sites of each patient were evaluated. It is important and essential for clinicians to investigate the relation of the upper posterior teeth roots with the maxillary sinus floor for the proper preoperative treatment planning in the maxillary posterior area (2). The ideal time for the loss of the first permanent molars is the age of 8-9 years, before the eruption of the second permanent molar (16). The early eruption of the second molar might establish a good contact relationship with the second premolar (17).

In this study, the amount of time that passed after the loss of the maxillary first permanent molars was during or after the eruption of the second permanent molars. Extractions of first permanent molars in these time intervals may result in some occlusal consequences including incomplete space closure, mesial tilting and distal drifting of the neighboring teeth, over-eruption of the opposing molar, and alveolar bone atrophy $(16,17)$.

The extraction of the maxillary second molars have reported to cause greater sinus expansion compared tothe extraction of maxillary first molars (15). Sharan and Madjar (15) reported that when two or more adjacent posterior teeth are extracted, the sinus volume become larger. The results of this study revealed an lesser expansion of the maxillary sinus floor in the edentulous sites. The negligible amount of sinus expansion could be attributed to there being only one tooth extraction and a transferring of functional forces to the area of the neighboring teeth.

Sinus pneumatization also occurs if mandibular posterior teeth have been missing for an extended time which leads the the opposing maxillary posterior teeth to overerupt (13). Tolstunov et al. (18) reported that the older edentulous patients tend to demonstrate higher rate of bone resorption in the maxilla which causes the enlargement of the sinuses. In the present study, the patients with extractions over six months prior to analysis presented the largest sinus expansions. Sinus also may expand due the presence of large defects in the extraction site and decreased bone resistance because of the extended healing period of the alveolar socket (14).

Several techniques are used to assess the relationship between the roots of the upper posterior teeth and the maxillary sinus $(2,4,12,13,15,16)$. Panoramic radiography allows the visualization of various anatomic structures, is widely available and relatively inexpensive (13). Its disadvantages include overlapping of the anatomical structures, distortion, magnification and inadequate resolution $(4,19)$. CBCT provides multiplanar images in expense to higher doses of radiation, being expensive, and limited availability (20). In this study, the supero-inferior differences of the sinus floor position were measured both in dentate and edentulous sites on the panoramic radiographs.

Atraumatic tooth extraction is important for the preservation of the alveolar bone volume and soft tissues as well (21). Schropp et al. (22) reported a significant reduction in the alveolar ridge width the within the first 3 months after single tooth extractions. Proper mechanics and light forces are recommended to reduce iatrogenic root resorption during orthodontic treatment through the maxillary sinus when the maxillary posterior teeth were extracted and space closure was selected as the treatment approach (13). The treatment plan for edentulous spaces always includes the option of implants in adults, but it is recommended to delay an implant placement until after the cessation of growth in children $(23,24)$.

\section{Conclusion}

This study demonstrated that the extraction of one maxillary first molar resulted in a negligible amount of sinus expansion in children. This can be related to the limited space left after the extraction of only one tooth for the sinus to expand and also to the transfer of the functional loads to the adjacent teeth.

Ethics Committee Approval: The Ethics Committee of Istanbul University, Faculty of Medicine has approved the present study protocol (2011/2108-895). 
Informed consent: Informed consent was provided by the participants' parents.

Peer review: Externally peer-reviewed.

Author contributions: SK and ES participated in designing the study. SK and MMA participated in generating the data for the study. GA and TLE participated in gathering the data for the study. APE and TLE participated in the analysis of the data. GA wrote the majority of the original draft of the paper. APE participated in writing the paper. All authors approved the final version of this paper.

Conflict of interest: The authors have no conflicts of interest to declare.

Financial disclosure: The authors declared that this study has received no financial support.

Türkçe öz: Çocuklarda maksiller birinci büyük azı dişi çekimine bağlı maksiller sinüs genişlemesinin değerlendirilmesi. Amaç: Bu çalışma, maksiller birinci büyük azı dişi çekiminin maksiller sinüsün genişlemesi üzerine etkisini anlamayı amaçlamıştır. Bireyler ve yöntem: Sadece bir maksiller birinci büyük azı dişi çekilmiş olan 119 hasta (yaşları 11-17) çalışma kapsamına alınmıştır. Hem dişli hem de dişsiz bölgelerde sinüs tabanı pozisyonunun superoinferior farkları, panoramik röntgenler üzerinde ölçülmüştür. Maksiller birinci büyük azı dişi çekimi sonrası maksiller sinüsün genişlemesi sabit anatomik yapılarla ilişkili olarak araştırılmıştır. Referans olarak interorbital hat (IL) ve iki zigomatik proses hattı (IZ) kullanılmıştır. IL ile dişsiz bölgelerdeki (ISX) ve dişli bölgelerdeki (IST) maksiller sinüsün (IS) alt sınırı arasındaki dikey mesafeler ölçülmüştür. Veriler istatistiksel olarak analiz edilmiştir. Bulgular:ISX'de maksiller sinüs genişleme miktarı IS $S_{T}^{\prime}$ ye göre istatistiksel olarak anlamlıydı ( $p<0.001)$. En büyük sinüs genişlemeleri, altı aydan daha uzun süre önce çekim yapılan hastalarda tespit edildi $(p<0.001)$. Maksiller sinüs genişlemesi ve $1 S_{T}$ miktarı arasında negatif korelasyon saptandı $(r=-0.438, p<0.001)$. Maksiller sinüs genişlemesi ve $I Z_{T}$ miktarı arasında pozitif bir korelasyon vardı $(r=23.8, p<0.009)$. Sonuç:Bu çalışma, bir maksiller birinci büyük azı dişi çekiminin çocuklarda önemsiz miktarda sinüs genişlemesi ile sonuçlandığını göstermiştir. Sonuçlar sadece bir diş çekimi olması ve komşu dişlerin alanına fonksiyonel kuvvetlerin aktarımı ile açıklanabilir. Anahtar kelimeler: Maksiller sinüs; sinüs genişlemesi; diş çekimi; panoramik röntgen; çocuk

\section{References}

1. Anderhuber W, Weiglein A, Wolf G. Nasal cavities and paranasal sinuses in newborns and children. Acta Anat (Basel) 1992;144:120-6. [CrossRef]

2. Kilic C, Kamburoglu K, Yuksel SP, Ozen T. An Assessment of the Relationship between the Maxillary Sinus Floor and the Maxillary Posterior Teeth Root Tips Using Dental Cone-beam Computerized Tomography. Eur J Dent 2010;4:462-7.

3. Karakas S, Kavakli A. Morphometric examination of the paranasal sinuses and mastoid air cells using computed tomography. Ann Saudi Med 2005;25:41-5. [CrossRef]

4. Wehrbein $\mathrm{H}$, Diedrich $\mathrm{P}$. The initial morphological state in the basally pneumatized maxillary sinus-a radiological-histological study in man. Fortschr Kieferorthop 1992;53: 254-62. [CrossRef]

5. Tatum HJr. Maxillary and sinus implant reconstructions. Dental Clinics of North America 1986;30:207-29.

6. Chanavaz M. Maxillary sinus: anatomy, physiology, surgery, and bone grafting related to implantology-eleven years of surgical experience. Journal of Oral Implantology 1990;16: 199-209.
7. Kubilius $M$, Kubilius $R$, Gleiznys $A$. The preservation of alveolar bone ridge during tooth extraction. Stomatologija, Baltic Dental and Maxillofacial Journal 2012;14:3-11.

8. Misch CE. Contemporary implant dentistry. 2nd Ed. St.Louis: CV Mosby Co. 1999, p 76-194.

9. Göçmen G, Borahan MO, Aktop S, Dumlu A, Pekiner FN, Göker K. Effect of Septal Deviation, Concha Bullosa and Haller's Cell on Maxillary Sinus's Inferior Pneumatization; a Retrospective Study. The Open Dentistry Journal 2015; 9:282-6. [CrossRef]

10. Brook I. Sinusitis of odontogenic origin. Otolaryngology -Head and Neck Surgery 2006; 135:349-55. [CrossRef]

11. Wehrbein $H$, Diedrich P. Progressive pneumatization of the basal maxillary sinus after extraction and space closure. Fortschr Kieferorthop 1992;53:77-83. [CrossRef]

12. Ariji Y, Kuroki T, Moriguchi S, Ariji E, Kanda S. Age changes in the volume of the human maxillary sinus: a study using computed tomography. Dentomaxillofac Radiol 1994; 23:163-8. [CrossRef]

13. Harorh, A, Bocutoglu O. The comparison of vertical height and width of maxillary sinus by means of Waters' view radiograms taken from dentate and edentulous cases. Ann Dent 1995;54:479.

14. Ohba T, Langlais RP, Morımoto $\mathrm{Y}$, Tanaka T, Hashimoto $\mathrm{K}$. Maxillary sinus floor in edentulous and dentate patients. Indian J Dent Res 2001;12:121-5.

15. Sharan A, Madjar D. Maxillary sinus pneumatization following extractions: a radiographic study. Int J Oral Maxillofac Implants 2008;23:48-56

16. Shahbazian M, Xue D, Hu Y, van Cleynenbreugel J, Jacobs R. Spiral Computed Tomography Based Maxillary Sinus Imaging in Relation to Tooth Loss, Implant Placement and Potential Grafting Procedure. Journal of Oral \& Maxillofacial Research 2010;1:7. [CrossRef]

17. Hadchiti W, Nasseh I, Hayek E, Mora F, Bouchard P. Prevalence, location and orientation of maxillary sinus septa. Annals of Oral \& Maxillofacial Surgery 2014;2(1):9.

18. Tolstunov L, Thai D, Arellano L. Implant-Guided Volumetric Analysis of Edentulous Maxillary Bone With ConeBeam Computerized Tomography Scan. Maxillary Sinus Pneumatization Classification. Journal of Oral Implantology 2012;38:377-90. [CrossRef]

19. Xie Q, Soikkonen K, Wolf J, Mattila K, Gong M, Ainamo A. Effect of head positioning in panoramic radiography on vertical measurements: an in vitro study. Dentomaxillofac Radiol 1996;25:61-6. [CrossRef]

20. Engstrom H, Chamberlain D, Kiger R, Egelberg J. Radiographic evaluation of the effect of initial periodontal therapy on thickness of the maxillary sinus mucosa. J Periodontol 1988; 59: 604-8. [CrossRef]

21. Bartee BK. Extraction site reconstruction for alveolar ridge preservation. Part 2: Membrane-assisted surgical technique. J Oral Implantol 2001;27:194-7. [CrossRef]

22. Schropp L, Wenzel A, Kostopoulos L, Karring T. Bone healing and soft tissue contour changes following single-tooth extraction: a clinical and radiographic 12-month prospective study. Int J Periodontics Restorative Dent 2003;23:313-23.

23. Shah RA, Mitra DK, Rodrigues SV, Pathare PN, Podar RS, Vijayakar HN. Implants in adolescents. Journal of Indian Society of Periodontology 2013;17:546-8. [CrossRef]

24. Op Heij DG, Opdebeeck H, van Steenberghe D, Quirynen M. Age as compromising factor for implant insertion. Periodontol 2003;33:172-84. [CrossRef] 